Research article

\title{
First report on three new diatom species from the Hooghly district, West Bengal
}

\author{
Nilu Halder* \\ Department of Botany, Raja Peary Mohan College, Uttarpara-712258, Hooghly, West Bengal, India \\ *Corresponding Author: niluhalder1@gmail.com \\ [Accepted: 17 September 2016]
}

\begin{abstract}
The present paper was communicated with the morpho-taxonomic description of three diatom taxa belonging to the order Pennales of the class Bacillariophyceae namely Fragilariopsis cylindrus, Achnanthidium lineare and Rhopalodia gibba var. ventricosa. Among them, the former species is rare in occurrence within freshwater ecosystem while the latter two species are found sparsely to abundant in pond, water reservoirs and other types of aquatic bodies. The limnological characteristics that supported their occurrences in water bodies were recorded and found to be congenial for their growth. The $\mathrm{pH}$ of water in studied aquatic bodies was observed alkaline and acceptable quantity of phosphate, nitrate-nitrogen and silica along with other physico-chemical parameters of waters were also noted. The above mentioned all three diatom taxa are new taxonomic reports from this district of West Bengal, India.
\end{abstract}

Keywords: New report - Diatoms - Hooghly - West Bengal - India.

[Cite as: Halder N (2016) First report on three new diatom species from the Hooghly district, West Bengal. Tropical Plant Research 3(3): 501-507]

\section{INTRODUCTION}

Diatoms are a major group of microscopic algae and the most common types of phytoplankton which are found in every habitat where water is present (Stoermer \& Smol 1999) and their (both fossils and living forms) well preserved siliceous frustules /cell walls make them ideal tools for various applied applications. Recently, they have been using in the other fields of studies as indicators of oil and gas exploration processes. They are now successfully used in comprehensive forensic examinations (Dwivedi \& Misra 2015) to detect the suspicious persons or murderers for crime investigations. It has been reported that their growth rate is faster in comparison to other phytoplanktonic taxa (Wetz \& Wheeler 2007). Thus, diatoms are important algal flora among the eukaryotic algae. They are beautiful microscopic organisms with various kinds of fabulous characteristics ornamentations on their frustules or cell walls. Especially, the presence of accessory pigments like fucoxanthin and universal $\beta$-carotene give them characteristic golden coloration. Generally, they grow in single cells as unicellular forms and sometimes form chains or simple colonies of various shapes like filaments or ribbons, fans, zigzags or stars in the aquatic bodies. They are capable of growing in different trophic levels of the water bodies. As the siliceous cell walls contain hydrated silicon dioxide $\left(\mathrm{SiO}_{2}\right)$ they do not decompose after death and henceforth, diatom beds or diatomite are being used as an important tool to study paleoecology, correlation analysis and to interpret or predict the phylogenetic evolutionary lineages as well as to calculate relative age dating of rocks being an important constituent of rock-forming microfossils.

The diatom flora is diverse in fresh water bodies, brackish and marine ecosystems and one of the richest algal groups in India due to having wide range of climate, topology and natural habitats. Their abundant growth is controlled by the physical as well as chemical conditions of water. According to You et al. (2009) their diversity depends on gradients of water, nutrients availability, $\mathrm{pH}$, temperature and altitudes of the habitats. Therefore, analysis of water has a great importance in the ecological study of diatoms.

Fragilariopsis Hust. is a planktonic diatom comprising of living as well as fossil species (Lundholm \& Hasle 2008). It is characteristically ribbon-shaped and valves outlines are linear with rounded apical ends. In the recent years, considerable taxonomic revisions have been made on the nomenclatural concept and generic placement of 
monoraphid achnanthoid diatoms since the publication of Lange-Bertalot \& Krammer (1989). They first removed the genus Achnanthes Bory from the family Achnanthaceae Kütz. and placed into two genera Achnanthidium Kütz. and Eucocconeis Cl. ex Meist. under the family Achnanthidiaceae D.G. Mann based on morphological and ecological features (Round et al. 1990, Potapova 2012). After that, a number of new genera have been created by splitting of Achnanthes Bory sensu lato. However, there are still a number of species, that have not yet been studied by LM (light microscopy) and SEM (scanning electron microscopy) or not transferred within this genus. The genus is abundant in rivers, streams and springs. They inhabit in clean and polluted waters. Their cells are small linear-lanceolate to lanceolate-elliptic with less than $30 \mu \mathrm{m}$ long and less than $5 \mu \mathrm{m}$ broad; consists of a concave raphe valve (RV) and a convex rapheless valve (RLV); uniseriate striae present on the RV which are comparatively denser towards the apices and the fine raphe is either straight or turned to one side (Ponader \& Potapova 2007).

The genus Rhopalodia O. Müll. includes 37 species of which at least 26 species are known only from the type samples from all over the world (VanLandingham 1967, Krammer 1988). It exhibited broader range of distributions, including fresh water, brackish and even marine environments. The valves are bracket-shaped in valve view with swollen in middle, indented at the central nodule, the apices are bent acutely. In girdle view, valves are lanceolate-elliptical, strongly swollen in the middle of the valve with broadly rounded apices. Raphe is excentric and chromatophore is single, laminate with irregularly margins.

The present work is focused on the morpho-taxonomic investigation of the fresh water diatom flora of the class Bacillariophyceae from Hooghly district, West Bengal, India. Few taxonomic works had been reported earlier from India (Venkataraman 1939, Biswas 1949, Gonzalves \& Gandhi 1952, Gandhi 1958, Sreenivasa \& Duthie 1973, Anand \& Kant 1976, Sarode \& Kamat 1979, 1980, Barhate \& Tarar 1981, Das \& Santra 1982, Patel \& Patel 1982, Venkateswarlu 1983, Prasad et al. 1984, Somshekar 1983, 1984, Chaturvedi 1985, Roy \& Sen 1985, Pal et al. 1986, Maity et al. 1987, Shukla \& Shukla 1987, Santra et al. 1989, Pal \& Santra 1990, Banerjee \& Santra 2001, Misra 2005, Bhakta et al. 2011, Das \& Adhikary 2012, Tripathi et al. 2012, Dwivedi \& Misra 2014). Except a single report (Halder \& Sinha 2015) there is no work in relation to exploration of diatom flora from this locality of West Bengal. Therefore, the present work was undertaken from this area. The main objectives of the present work were to identify, explore the diversity of diatom algal flora and documentation of them in respect of ecology from this state.

\section{MATERIALS AND METHODS}

The diatom specimens had been collected from different places viz. Chinsurah (22 $\left..90^{\prime} \mathrm{N} ; 88^{\circ} .39^{\prime} \mathrm{E}\right)$, Ganga river at Tribeni $\left(22^{\circ} .99^{\prime} \mathrm{N} ; 88^{\circ} .39^{\prime} \mathrm{E}\right)$ and Kuntighat $\left(23^{\circ} .01^{\prime} \mathrm{N} ; 88^{\circ} .41^{\prime} \mathrm{E}\right)$ of Hooghly district in West Bengal, India. The light microscopic (LM) taxonomic study of the cleaned diatom specimens was made under Olympus compound microscope with camera attachment (Model No. CH20i) and photographs were taken using Canon A480 camera. Samples were preserved in $4 \%$ formalin. The organic contents particularly calcium and irons were removed from the diatom samples by the acid digestion method in which $4 \mathrm{ml}$. of concentrated $\mathrm{HCl}(30 \%)$ and $2 \mathrm{ml}$. of saturated potassium permanganate $\left(\mathrm{KMnO}_{4}\right)$ solution were added with $2 \mathrm{ml}$. of diatom sample as mentioned in materials \& methods (Mitić-Kopanja et al. 2014). Cleaned diatoms were mounted with DPX mounting medium. The ecological study was carried out following the standard method described earlier by the author/s (Halder 2015a,b,c,d, Halder \& Sinha 2014,2015, Halder 2016a,b). Identification of those algal species were done by following standard monographs and scientific literature viz. Hustedt (1930), Hirano (1955), Foged (1977), Lundholm \& Hasle (2008), Cefarelli et al. (2010), Van De Vijver et al. (2011), Al-Hassany \& Hassan (2014) etc.

\section{RESULTS AND DISCUSSION}

A total number of three diatom taxa belonging to the order Pennales of the class Bacillariophyceae had been morpho-taxonomically described with author citation, habitat, collection number, date of collection, significance, species abundance and ecology for the first time. Each currently accepted names had been provided with its author(s) name. All the limnological parameters except temperature and $\mathrm{pH}$ were expressed as $\operatorname{mg} .1^{-1}$.

1. Fragilariopsis cylindrus (Grunow) Helm. \& Krieg. in Diatomeenschalen 2: 17, pl. 187-189, 1954; Hasle in Skr. Norske Vidensk Akad. I. Mat. Nat. Kl. NS. 21: 34-37, pl.12, figs. 6-12; pl. 14, figs. 1-10; pl. 17, figs. 2-4, 
1965; Lundholm \& Hasle in Nov. Hedw., Beiheft 133, 237-241, figs. 1-6, 12-14, 17, 19, 20, 22-23, 2008; Cefarelli et al., in Pol. Biol. 33: 1467, 70, 81: figs. 2e-i, 7c-e, 2010. (Fig. 1A)

Synonym(s): Fragilaria cylindrus Grunow; Nitzschia cylindrus (Grunow) Hasle

Description: Planktonic, cells solitary or chain-forming, ribbon-shaped, attached by the valve surfaces and each cell contains two rectangular chloroplasts in the girdle view; valve shape linear and isopolar with broadly rounded ends; apical axis 14.0-23.0 $\mu \mathrm{m}$; transapical axis 2.0-3.0 $\mu \mathrm{m}$; transapical striae 12-16 in $10 \mu \mathrm{m}$; at the ends, the striae become nearly parallel to the apical axis; striae perforated and consist of 2 or rarely 3 rows of minute poroid areolae, each with 40-60 poroids in $10 \mu \mathrm{m}$; fibulae (continuations of costae) occur at approximately the same density as the striae; raphe canal is eccentric.

Habitat: Ganga river water at Tribeni site, Hooghly district, West Bengal.

Collection No: NH 804; Dated: 03.01.2011

Significance: Primary producer and a component of food chain in aquatic ecosystem.

Species abundance: Rare in Hooghly district, West Bengal.

2. Achnanthidium lineare W. Sm. in Ann. \& Mag. Nat. Hist. 2(15): 8, pl.1, fig. 9, 1855; Van De Vijver et al. in Algol. Stud. 136/137: 170-180, figs. 1-35, 2011. (Fig. 1B)

Synonym(s): Achnanthes linearis (W. Sm.) Grunow; Achnanthes minutissima Kütz. partim sensu Krammer \& Lange-Bertalot, Rossithidium lineare (W. Sm.) Round et Bukht.

Description: Frustules in girdle view rectangular; valves linear or linear-lanceolate with almost parallel margins; valve apices broadly rounded, non-protracted; rapheless and raphe valves are linear; valve length 12.0$13.5 \mu \mathrm{m}$, width $2.5-2.8 \mu \mathrm{m}$; axial area narrower, linear, weakly widening towards the central area; central area rectangular fascia; raphe filiform straight with raphe endings; striae radiate to weakly radiate throughout the entire valve; $28-32$ in $10 \mu \mathrm{m}$; striation pattern slightly to densely spaced near apices; numbers of areolae per stria $2-3$ but in this specimen striae and areolae not visible.

Habitat: Pond water at Kuntighat, Hooghly district, West Bengal.

Collection No: NH 509; Dated: 04.07.2009

Significance: Primary producer and a component of aquatic food chain in this pond.

Species abundance: Sparsely present in Hooghly district, West Bengal.

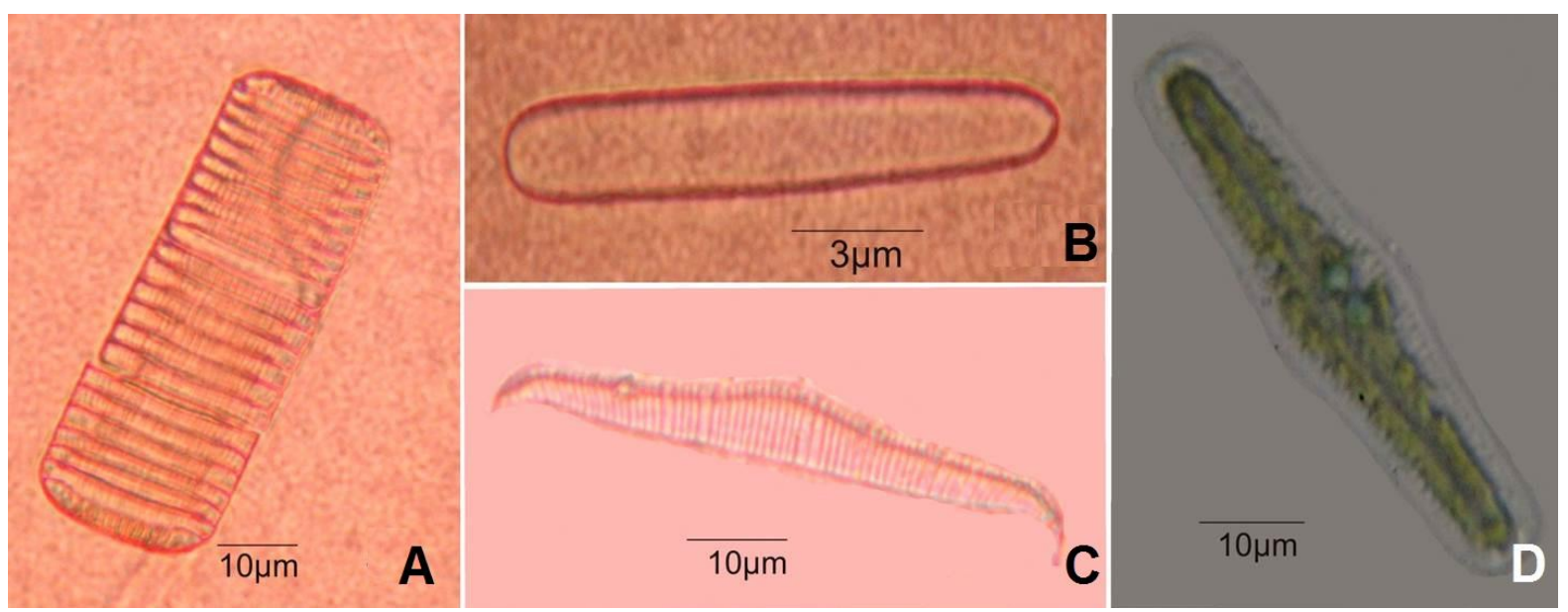

Figure 1. A. Fragilariopsis cylindrus; B. Achnanthidium lineare; C-D. Rhopalodia gibba var. ventricosa (valve \& girdle views).

3. Rhopalodia gibba var. ventricosa (Kütz.) H. Perag. \& M. Perag. in Diat. Mar. France 302, pl. 77, figs. 3-5, 1900; Patrick \& Reimer, The diatom of the United States, 190, pl. 28, figs. 3-4, 1975; Foged, Fresh Water Diatoms in Ireland, 106, pl. 43, fig. 7, 1977; Czarnecki \& Blinn in Biblioth. Phycol. 102 , pl. 22 , fig. 12, 1978; Hadi et al. in Nov. Hedw., 534, pl. 12, fig. 217, pl. 37, fig. 3, 1984; Al-Hassany \& Hassan, Asian J. Natl. \& Appl. Sci. 3(1): 2, pl. 1, fig. 1, 2014. (Fig. 1C-D)

Description: Planktonic, frustules bracket shaped in valve view with swollen middle, apices acutely bent and margin convex; in girdle view, valves linear-elliptical, inflated in median portion with broadly rounded poles; valves $50.5-54.5 \mu \mathrm{m}$ long and $9.5-10.0 \mu \mathrm{m}$ broad, having sometimes median constrictions; ventral margin 
straight, arcuate or curve at the ends; dorsal margin convex; chromatophore is single in each cell, laminate with irregular margins; striae slightly radiate to parallel; costae 8 and striae 15 in $10 \mu \mathrm{m}$.

Habitat: Water reservoir in rice field at Chinsurah, Hooghly, West Bengal.

Collection No: NH 840; Dated: 18.06.2011

Significance: Primary producer in water bodies.

Species abundance: Abundant in Hooghly district, West Bengal.

In the recent work, three freshwater diatom taxa had been morpho-taxonomically described from this IndoGangetic plain of West Bengal, India. Fragilariopsis cylindrus sensu lato is a cold-water diatom species and was documented from polar and subpolar regions in the Arctic, Antarctic and open water as well as in ice although, a small number of species have been recorded exclusively from the higher latitudes of the Northern Hemisphere (Witkowski et al. 2000, Lundholm \& Hasle 2008). It could dominate the water column, sea ice and ice edge communities (Hegseth \& von Quillfeldt 2002, Cefarelli et al. 2010). Therefore, the species of the genus Fragilariopsis Hust. is abundant particularly in the sea, Arctic and Antarctic ice waters. But here, author collected the species of $F$. cylindrus (Grunow) Helm. \& Krieg. from the lower stretch (downstream) of river Hooghly (Ganga) at Tribeni site during winter when water temperature was below the level of $20^{\circ} \mathrm{C}$ from West Bengal, India. It is morphologically similar to F. curta (Van Heurck) Hust. and F. kerguelensis (O'Meara) Hust. but differs it from those two species by having isopolar apical axes. The shape, measurements of valves and other identifying characteristics of this species also agreed with the type specimen and other published reports (von Quillfeldt 2001, Lundholm \& Hasle 2008, Cefarelli et al. 2010). It was collected as planktonic form like Kang \& Fryxell (1992). The description of species Achnanthidium lineare W. Sm. is exactly coincided with the type specimens and the valve length and width of the present specimen is matched with the European type materials especially of Scotland and France (Van De Vijver et al. 2011). The taxon Rhopalodia gibba var. ventricosa (Kütz.) H. Perag. \& M. Perag. is differentiated from $R$. gibba (Ehr.) O. Müll. by i) its marked swelling in the middle of the valve ii) more elliptical nature of frustule in girdle view and iii) length: breadth ratio is much less than in $R$. gibba (Ehr.) O. Müll.

\begin{tabular}{|c|c|c|c|}
\hline \multirow{2}{*}{$\begin{array}{l}\text { Limnological } \\
\text { parameters }\end{array}$} & \multicolumn{3}{|c|}{ Different Sampling Sites } \\
\hline & Reservoir at Chinsurah & River Ganga at Tribeni & Pond at Kuntighat \\
\hline Temp. $\left({ }^{\circ} \mathrm{C}\right)$ & $31^{\circ} \mathrm{C} \pm 0.18$ & $19^{\circ} \mathrm{C} \pm 0.13$ & $30^{\circ} \mathrm{C} \pm 0.17$ \\
\hline $\mathrm{pH}$ & $8.1 \pm 0.05$ & $7.3 \pm 0.05$ & $7.8 \pm 0.05$ \\
\hline DO $\left(\mathrm{mg} . \mathrm{l}^{-1}\right)$ & $7.4 \pm 0.11$ & $7.0 \pm 0.12$ & $7.1 \pm 0.11$ \\
\hline $\mathrm{BOD}\left(\mathrm{mg} \cdot \mathrm{l}^{-1}\right)$ & $4.0 \pm 0.05$ & $4.5 \pm 0.11$ & $4.3 \pm 0.13$ \\
\hline $\operatorname{COD}\left(\mathrm{mg} \cdot \mathrm{l}^{-1}\right)$ & $90.0 \pm 5.77$ & $120.0 \pm 2.88$ & $110 \pm 2.88$ \\
\hline $\mathrm{NO}_{3}-\mathrm{N}\left(\mathrm{mg} \cdot \mathrm{l}^{-1}\right)$ & $0.25 \pm 0.05$ & $0.12 \pm 0.05$ & $0.30 \pm 0.08$ \\
\hline $\mathrm{PO}_{4}^{3-}\left(\mathrm{mg}^{3} \mathrm{l}^{-1}\right)$ & $0.34 \pm 0.11$ & $0.18 \pm 0.12$ & $0.28 \pm 0.15$ \\
\hline Silicate $\left(\mathrm{mg} . \mathrm{l}^{-1}\right)$ & $3.6 \pm 0.13$ & $6.6 \pm 0.13$ & $5.4 \pm 0.14$ \\
\hline $\mathrm{SO}_{4}^{2-}\left(\mathrm{mg} . .^{-1}\right)$ & $6.0 \pm 0.22$ & $6.8 \pm 0.17$ & $7.0 \pm 0.20$ \\
\hline Total alkalinity (mg. $\left.1^{-1}\right)$ & $220.0 \pm 0.20$ & $164.0 \pm 0.22$ & $184.0 \pm 0.22$ \\
\hline
\end{tabular}

The physico-chemical characteristics of different types of water bodies during the diatom sampling times were measured and depicted in table 1 . The $\mathrm{pH}$ of the studied aquatic ecosystems was found to be alkaline. Kamat (1965) reported that the diatoms are usually abundantly found in the alkaline water bodies. Thus, the present investigation confirmed the earlier finding. The ranges of nitrate-nitrogen and phosphate values were measured from $0.12-0.30 \mathrm{mg} . \mathrm{l}^{-1}$ and $0.18-0.34 \mathrm{mg} . \mathrm{l}^{-1}$ respectively while; silicate was recorded as $3.6-6.6 \mathrm{mg} .1^{-1}$. This study revealed that presence of adequate amount of nitrate-nitrogen, phosphate and silicate along with other selected physico-chemical parameters favored the growth of those diatom species in the above said water bodies. The investigation also revealed that they can tolerate varying degrees of temperatures $\left(19-31^{\circ} \mathrm{C}\right), \mathrm{pH}$ $(\mathrm{pH}=7.3-8.1)$ and total alkalinity $\left(164.0-220.0 \mathrm{mg} . \mathrm{l}^{-1}\right)$ values. Other parameters like BOD and $\mathrm{SO}_{4}{ }^{2-}$ except COD values were found in lower amounts in the water bodies. DO was observed between $7.0 \mathrm{mg} . \mathrm{l}^{-1}$ and 7.4 mg. $1^{-1}$ which is higher that might be due to maximum abundance of diatom and other plankton flora. Henceforth, it can be summarized that these species appear in those aquatic ecosystems which are enriched with sufficient essential nutrients. This documentation of diatom species of fresh water habitats from poorly studied region has 
a great significance for future investigations on algal taxonomy and freshwater ecology.

\section{ACKNOWLEDGEMENTS}

The author is grateful to Dr. Sankar Narayan Sinha, Dept. of Botany, University of Kalyani, Nadia, West

Bengal, India for providing opportunity to work under his guidance, co-operations and valuable suggestions.

\section{REFERENCES}

Al-Hassany JS \& Hassan FM (2014) Taxonomic study of some epiphytic diatoms on aquatic plants from AlHawizah marshes, Southern of Iraq. Asian Journal of Natural \& Applied Sciences 3(1): 1-11.

Anand VK \& Kant S (1976) Diatoms of Jammu Mansar lake. Geobios 3: 34-36.

Banerjee A \& Santra SC (2001) Phytoplankton on the rivers of Indian Sunderban mangrove estuary. Indian Biologist 33(1): 67-71.

Barhate VP \& Tarar JL (1981) The Algal flora of Tapti river of Bhusawal, Maharashtra. Phycological Society of India 20(1\&2): 75-78.

Bhakta S, Das SK, Nayak M, Jena J, Panda PK \& Sukla LB (2011) Phyco-diversity assessment of Bahuda river mouth areas of east coast of Odisha, India. Recent Research in Science and Technology 22(4): 80-89.

Biswas KP (1949) Common fresh water and brackish water algal flora of India and Burma. Pt. I. Records of the Botanical Survey of India 15: 1-105.

Cefarelli AO, Ferrario ME, Almandoz GO, Atencio AG, Akselman R, Vernet M (2010) Diversity of the diatom genus Fragilariopsis in the Argentine sea and Antarctic waters: morphology, distribution and abundance. Polar Biology 33: 1463-1484.

Chaturvedi UK (1985) Additions to algal flora of Rohilkhand division, U.P., India: IX. Diatoms from Bareilly district. Phycological Society of India 24: 163-169.

Czarnecki DB \& Blinn DW (1978) Diatoms of the Colorado river in Grand Canyon national park and vicinity (Diatoms of Southwestern U.S.A. II) Bibliotheca Phycologica 38: 1-181.

Das PR \& Santra SC (1982) Diatoms of Senchal lake, Darjeeling, West Bengal. Phycological Society of India 21: 99.

Das SK \& Adhikary SP (2012) Diversity of freshwater algae in Arunachal Pradesh and their distribution in different altitudes. The Journal of the Indian Botanical Society 91(1-3): 160-182.

Dwivedi RK \& Misra PK (2014) On the occurrence of freshwater diatoms of southern Himachal Pradesh, India. Phycological Society of India 44(1): 17-24.

Dwivedi RK \& Misra PK (2015) Freshwater Diatoms from Himalayan State Himachal Pradesh, India. Phycological Society of India 45(1): 30-39.

Foged N (1977) Fresh water diatoms in Ireland. J. Cramer, Germany, pp. 1-220.

Gandhi HP (1958) Fresh water diatoms from Kolhapur and its immediate environments. Journal of the Bombay Natural History Society 55(3): 493-511.

Gonzalves EA \& Gandhi HP (1952) A systematic account of the diatoms of Bombay and Salsette, Part I. The Journal of the Indian Botanical Society 31(3): 117-151.

Hadi RAM, Al-Saboonchi AA \& Haroon AKY (1984) Diatoms of the Shatt Al-Arab river, Iraq, Nova Hedwigia 39: 513-557.

Halder N \& Sinha SN (2014) New Records of Euglena acus (O.F. Müll.) Ehr. and Phacus acuminatus (A. Stokes) Huber-Pestalozzi of Euglenineae from Hooghly District, West Bengal. Journal of Academia and Industrial Research 3(7): 333-336.

Halder N \& Sinha SN (2015) New report of four Bacillariophycean algal species from West Bengal, India. Journal of Algal Biomass Utilization 6(2): 28-31.

Halder N (2015a) Two species of Zygnemopsis (Skuja) Transeau from West Bengal, India. Tropical Plant Research 2(2): 82-84.

Halder N (2015b) Morpho-taxonomy of Hydrodictyon reticulatum (L.) Lagerheim and Pediastrum tetras var. tetraodon (Corda) Hansgirg, Hooghly, West Bengal, India. Tropical Plant Research 2(3): 168-171.

Halder N (2015c) Taxonomy and ecology of Coleochaete irregularis Pringsheim and Coleochaete orbicularis Pringsheim, West Bengal, India. Journal of Algal Biomass Utilization 6(4): 47-49.

Halder N (2015d) Limnological study of Dwarkeshwar river water in the downstream at Arambagh, Hooghly district, West Bengal, India. Spring 5: 10-14. 
Halder N (2016a) Note on Ankistrodesmus Corda and Kirchneriella Schmidle in Hooghly, West Bengal, India. Mesopotamia Environmental Journal 2(2): 40-46.

Halder N (2016b) Taxonomy and periodicity of Chlorococcum fries, Coelastrum Näg. and Scenedesmus Meyen in Hooghly, West Bengal, India. Mesopotamia Environmental Journal 2(2): 47-56.

Hegseth EN \& von Quillfeldt CH (2002) Low phytoplankton biomass and ice algal blooms in the Weddell sea during the ice-filled summer of 1997. Antarctic Science 14(3): 231-243.

Hirano M (1955) Fresh water Algae. In: Kihara H (ed) Fauna and flora of Nepal Himalaya. Fauna \& Flora Research Society, Kyoto University, Japan, pp. 5-42.

Hustedt F (1930) Bacillariophyta (diatomeae) in Pascher's Süsswasser-flora Mitteleuropas. Verlag. Gust. Fischer, Heft, 10. pp. 1-466.

Kamat MD (1965) Ecological notes on the algae of Kolhapur. Journal of Biological Sciences 8: 47-54.

Kang SH \& Fryxell GA (1992) Fragilariopsis cylindrus (Grunow) Krieger: The most abundant diatom in water column assemblages of Antarctic marginal ice edge zones. Polar Biology 12: 609-627.

Krammer K (1988) The Gibberula-group in the genus Rhopalodia O. Müller(Bacillariophyceae). I. Observations on the valve morphology. Nova Hedwigia 46: 277-303.

Lange-Bertalot H \& Krammer K (1989) Achnanthes, eine Monographie der Gattung mit Definition der Gattung Cocconeis und Nachträgen zu den Naviculaceae. Bibliotheca Diatomologica 18: 1-393.

Lundholm N \& Hasle GR (2008) Are Fragilariopsis cylindrus and Fragilariopsis nana bipolar diatoms? Morphological and molecular analyses of two sympatric species. Nova Hedwigia, Beihefte, 133: 231-250.

Maity H, Bandyopadhyaya G \& Santra SC (1987) Algal flora of saline habitats of Sundarban, West Bengal and its possible role in reclamation of soil. The Journal of the Indian Society Coastal Agricultural Research 5(1): 325-331.

Misra PK, Srivastava AK, Prakash J, Asthana DK \& Rai SK (2005) Some fresh water algae of eastern Uttar Pradesh, India. Our Nature 3: 77-80.

Mitić-Kopanja D, Wetzel CE, Ector L \& Levkov Z (2014) Two new Gomphonema Ehrenberg (Bacillariophyceae) species from Macedonia and comparison with type material of G. brebissonii Kützing. Fottea, Olomouc, 14(2): 149-160.

Pal TK, Adhya TK \& Santra SC (1986) Algal flora of Murshidabad district,W.B. I. A survey from Berhampore and adjoining areas. Bulletin of the Botanical Society of Bengal 40: 33-43.

Pal UC \& Santra SC (1990) Algae of Midnapore, West Bengal II. Bacillariophyceae. Phycological Society of India 29(1\&2): 73-81.

Patel RJ \& Patel BR (1982) Achnanthes hauckiana Grun. from Gujarat coast. Phycological Society of India 21: 131-134.

Patrick R \& Reimer CW (1966) The diatom of the United States exclusive of Alaska and Hawaii.Vol.1. Philadelphia: Academy of Natural Sciences, pp. 1-688.

Ponader KC \& Potapova MG (2007) Diatoms from the genus Achnanthidium in flowing waters of the Appalachian mountains (North America): Ecology, distribution and taxonomic notes. Limnologica- Ecology \& Management of Inland Waters 37(3): 227-241.

Potapova M (2012) New species and combinations in monoraphid diatoms (family Achnanthidiaceae) from North America. Diatom Research 27(1): 29-42.

Prasad BN \& Srivastava MN (1992) Freshwater algal flora of Andaman and Nicobar Islands, Vol. I. Bishen Singh Mahendra Pal Singh, Dehradun, pp. 1-369.

Prasad BN, Jaitly YC \& Mishra PK (1984) Some diatoms from the hot springs of Ladakh. Geophytology 14 (2): $156-160$.

Round FE, Crawford RM \& Mann DG (1990) The diatoms: biology and morphology of the genera. Cambridge University Press, Cambridge, pp. 1-747.

Roy M \& Sen N (1985) Fresh water algae of Chattisgarh. Phycological Society of India 24: 76-79.

Santra SC, Pal UC, Das TM, Sen S, Saha R, Datta S \& Ghosh Dastidar P (1989) Phytoplanktons of BhagirathiHooghly estuary: An illustrative accounts. Indian Biologist 21(1): 1-27.

Sarode PT \& Kamat ND (1979) Diatoms of Marathwada, Maharashtra-I. Phycological Society of India 18: 2532.

Sarode PT \& Kamat ND (1980) The diatom flora of Nagpur, India. Nova Hedwigia 32: 797-838. 
Shukla BK \& Shukla AC (1987) A contribution to the algal flora of Kanpur. Phycological Society of India 26: 82-85.

Somshekar RK (1983) Algal flora of river Cauvery, Karnataka II. Diatoms. Phycological Society of India 22: 81-85.

Somshekar RK (1984) Contribution of the Algal flora river Kaplia, Karnataka II. Diatoms. Phycological Society of India 23: 125-129.

Sreenivasa MR \& Duthie HC (1973) Diatom flora of the Grand river, Ontario, Canada. Hydrobiology 42: 161224.

Stoermer F \& Smol JP (1999) The diatoms: Applications for the environmental and earth sciences. Cambridge University Press, Cambridge, U.K, pp.1-466.

Tripathi SK, Misra U \& Misra PK (2012) Diatom Flora of Western Uttar Pradesh, India. Phycological Society of India 42(2): 14-34.

Van De Vijver B, Ector L, Beltrami ME, De Haan M, Falasco E, Hlúbiková D, Jarlman A, Kelly M, Novais MH \& Wojtal AZ (2011) A critical analysis of the type material of Achnanthidium lineare W. Sm. (Bacillariophyceae). Algological Studies 136/137: 167-191.

VanLandingham SL (1967) Catalogue of the fossil and recent genera and species of diatoms \& their synonyms. Part I. Acanthoceros through Bacillaria. J. Cramer, Lehre, pp. 1-493.

Venkataraman, G. 1939. A systematic account of some south Indian diatoms. Proceedings of the Indian Academy of Science 10(6): 293-368.

Venkateswarlu V (1983) Taxonomy and ecology of algae in the river Moosi, Hyderabad. Bibliotheca Phycologica 66: 1-41.

von Quillfeldt CH (2001) Identification of some easily confused common diatom species in Arctic spring blooms. Botanica Marina 44: 375-389.

Wetz MS \& Wheeler PA (2007) Release of dissolved organic matter by coastal diatoms. Limnology \& Oceanography 52(2): 798-807.

Witkowski A, Lange-Bertalot H \& Metzeltin D (2000) Diatom flora of marine coasts I. In: (eds) Lange-Bertalot H: Iconographia Diatomologica. Gantner ARG, Ruggell, Liechtstein, pp. 5-925.

You Q, Liu Y, Wang Y \& Wang Q (2009) Taxonomy and distribution of diatoms in the genera Epithemia and Rhopalodia from the Xinjiang Uygur Autonomous Region, China. Nova Hedwigia 89(3-4): 397-430. 